\title{
СТАН ФІЗИЧНОЇ ПІДГОТОВЛЕНОСТІ ДІТЕЙ 10-ТИ РОКІВ ЯК КРИТЕРІЙ ГОТОВНОСТІ ДО ЗАНЯТЬ АКТИВНИМ ТУРИЗМОМ
}

\begin{abstract}
Мета - визначити стан фізичної підготовленості школярів 10-ти років як критерій їх готовності до занять активним туризмом. Матеріал і методи дослідження: теоретичний рівень (контентаналіз науково-методичної літератури, отриманих результатів, компаративний аналіз, узагальнення); емпіричний рівень (педагогічне тестування фізичної підготовленості, педагогічний експеримент); методи математичної статистики. У дослідженні взяло участь 52 школярі віком десять років. Результати і висновок. Отримані результати та висновки. Проведене дослідження виявило, щуо найкраще в 10-річних школярів закладів загальної середньої освіти сформовані такі якості як динамічна сила різних груп м'язів та динамічна рівновага, загальна витривалість, а також відчуття простору. Однак, низка якостей таких як статична сила м'язів рук $і$ ніг, статична рівновага $і$ загальна координованість рухів у дітей молодшого шкільного віку знаходяться на низькому і нижчому за середній рівнях.

Отримані результати свідчать про недостатню фізичну підготовленість дітей до здійснення туристичної діяльності та вказують на необхідність оптимізації спеціально організованої рухової активності.
\end{abstract}

Ключові слова: фізична підготовленість, активний туризм, школярі 10-ти років

The purpose is to determine physical preparedness state of 10-years-old schoolchildren as a criterion of their readiness to active tourism activity. Methods of research: theoretical level (content analysis of scientific methodological literature, obtained results, comparative analysis, generalization); empirical level (pedagogical testing of physical preparedness, pedagogical experiment); mathematical statistics methods. 52 schoolchildren aged 10 were involved in the study. To test the physical preparedness of 10-years-old schoolchildren there was used a test battery that contained control exercises, which on our opinion are most essential for successful active tourism implementation, namely the development of such physical abilities as agility (shuttle $3 \times 10 \mathrm{~m} \mathrm{run} \mathrm{test),}$ orientational abilities, static equilibrium (Flamingo test), dynamic equilibrium (BESS technique), strength abilities of different muscles groups (low bar pull-up test; sit-up test for $1 \mathrm{~min}$; flexed-arm hang test, the wall-sit test), aerobic endurance (6-minute run test). Motor tests assessment was carried out according to State tests and norms of assessment of physical training of the population of Ukraine. Results and conclusion. The study showed that most schoolchildren showed high, above average and average results for such physical abilities development as dynamic balance (100\%), hands muscle dynamic strength (98,08\%), abdominal muscular dynamic strength $(61,54 \%)$, aerobic endurance (59.62\%), and space differentiation (61.54\%). However, such physical abilities as muscular static strength of hands (94,23\%) and feet (88,46\%), general coordination abilities development $(75,00 \%)$ and static equilibrium $(71,16 \%)$ in early school-age children are low and below the average levels.

The obtained results testify about lack of children physical preparedness for tourism activity and indicate the need for specially organized motor activity optimization.

Key words: physical preparedness, active tourism, 10 years-old schoolchildren.

Постановка проблеми та аналіз результатів останніх досліджень. Одним 3 основних завдань Національної стратегії розвитку освіти в Україні на період до 2021 року $\epsilon$ формування гармонійно розвиненої, морально і фізично здорової особистості, яка 3 відповідальністю ставиться до свого здоров'я. Останнім часом все більше занепокоєння викликає рівень фізичного стану дітей шкільного віку. На жаль, 3 кожним роком навчання у школі кількість здорових дітей знижується [1]. Аналіз та узагальнення даних наукових праць дозволив виділити такі напрями розв'язання проблеми підвищення рівня фізичного стану дітей молодшого шкільного віку: розробка нових освітніх та оздоровчо-рухових технологій навчання $[4 ; 5 ; 12]$, впровадження системи педагогічного контролю компонентів фізичного стану дітей $[2 ; 13]$, удосконалення програмно-нормативних засад фізичного виховання [6;9; 15]. На думку дослідників [15], проблему оздоровлення дітей можна вирішити саме за рахунок проведення позакласних занять. Такі заняття реалізуються у формі рекреаційно-оздоровчої рухової активності. Великої 
популярності сьогодні набуває туризм, що є одним з найдоступніших видів оздоровлення. Туризм несе в собі величезний потенціал засобів рекреаційно-оздоровчої діяльності школярів. Туризм реалізується як засіб оздоровчої діяльності [7]; комплекс засобів фізичного виховання школярів [5]; засіб підвищення функціональних резервів організму [7]. Адже відомо, що активний туризм з його великими, але рівномірно розподіленими в часі навантаженнями, позитивно впливає на психофізичний стан дітей, дозволяє моделювати реальні життєві ситуації і спонукає до конкретних поведінкових дій [3].

Дослідження проблеми використання засобів оздоровчого туризму у фізичному вихованні дітей молодшого шкільного віку показали їх фрагментарний характер [2; 3; 5; 7]. Відкритими залишаються питання організації та проведення позакласних занять на основі засобів оздоровчого туризму з молодшими школярами. Все це не дозволяє повною мірою реалізувати потенціал оздоровчого туризму як універсального засобу підвищення рівня фізичного стану школярів.

Виходячи зі сказаного, актуальність дослідження зумовлена, з одного боку, наявністю досліджень, що доводять ефективність туризму в роботі зі школярами і браком наукових робіт щодо використання засобів туризму в оздоровчо-спортивній роботі 3 учнями, а з іншого - необхідністю розробки, наукового обгрунтування та експериментального вивчення рекреаційно-оздоровчої технології підвищення рівня фізичної підготовленості молодших школярів через засоби активного туризму.

Мета дослідження - визначити стан фізичної підготовленості школярів 10-ти років як критерій їх готовності до занять активним туризмом.

Методи та організація дослідження. У роботі були використані загальноприйняті наукові методи та методики: теоретичний рівень досліджень (контент-аналіз науково-методичної літератури $з$ проблеми дослідження, отриманого емпіричного фактажу, узагальнення); емпіричний рівень досліджень (педагогічне тестування фізичної підготовленості, педагогічний експеримент); методи математичної статистики [10].

Для тестування фізичної підготовленості учнів 10-ти років була сформована батарея тестів, яка містила контрольні вправи, які, на нашу думку, є найбільш необхідними для успішної реалізації занять активним туризмом, а саме виявлення розвитку таких фізичних здібностей як спритність (човниковий біг $3 \times 10$ м [11]), орієнтаційних здібностей (за методикою [2]), статичної рівноваги (тест “Фламінго” [11]), динамічної рівноваги (методика БЕСС [11]), силових здібностей різних груп м'язів (підтягування у напіввисі (кількість разів); піднімання тулуба в сід за 1 хв (кількість разів); вис на зігнутих руках (c) [11], утримання пози напівприсяд [11]), а також загальної витривалості (6-хвилинний рівномірний біг [11]). Оцінювання рухових тестів проводилося за Державними тестами і нормативами оцінки фізичної підготовленості населення України [14].

Враховуючи, що розвиток орієнтаційних здібностей залежить від сформованості просторових сприймань і уявлень, вивчення проводилося в трьох напрямах: а) пробігання десятиметрового відрізка “змійкою” між комбінаціями символів - для оцінки рухової орієнтаційної здібності; б) для вивчення топографічних уявлень дітей, розуміння ними деяких просторових категорій і основних напрямів руху виконувалися 14 завдань, які виявляли можливості дітей орієнтуватися “на собі” (показати у себе і самостійно назвати різні частини тіла); в) визначати просторові відносини між суб'єктом і об'єктом, орієнтуючись “від себе”, “від предмета” (назвати предмет зліва, навпаки, справа тощо); виявляти здібності дітей орієнтуватися “на собі” в процесі рухових дій (дістати правою рукою носок лівої ноги); визначати основні напрями простору в русі (повернути ліворуч, праворуч, зробити крок вперед). Оцінка результатів проводилася за дихотомічною системою: за правильне виконання завдання нараховувався 1 бал, за виконання 3 помилкою - 0 балів; для вивчення здібностей дітей орієнтуватися на 
горизонтальній площині застосовувалася стандартизована діагностична методика [2]. Методика містила два вступних і десять основних завдань, в яких використовувалися умовно-схематичні зображення у вигляді системи предметних орієнтирів, лінійної схеми шляху та поєднання схеми шляху з предметними орієнтирами. Перевірка здійснювалася у формі ігрового пошуку захованого в будиночку листа. Ця методика виявляє вміння користуватися різними типами умовно-схематичних зображень для орієнтування в просторі і дозволяє дати характеристику сформованих просторових уявлень у дітей.

Дітям пропонувалося вирішення двох вступних завдань. Рішення завдань перевірялися, помилки пояснювалися і виправлялися, тільки тоді вирішувалися основні завдання.

У дослідженні взяло участь 52 дітей віком 10-ти років Крихівецької ЗОШ м. Івано-Франківська. Представлений контингент учнів був задіяний у дослідженні добровільно при письмовій згоді батьків на участь у всіх етапах педагогічного експерименту, а також на подальший аналіз й оприлюднення їх особистих даних під час розгляду та висвітлення результатів дослідження.

Результати дослідження та їх обговорення. Одним з критеріїв готовності до занять активним туризмом у будь-якому віці є стан фізичної підготовленості, в цілому, та необхідних рухових здібностей, зокрема.

Аналіз результатів тестування учнів 10-ти років свідчить про різноспрямовані тенденції при прояві тих чи інших фізичних здібностей.

Так, жоден школяр у тестовій вправі “підтягування у напіввисі” не показав результату, який відповідав би низькому рівню розвитку динамічної сили м'язів рук, нижче середній рівень продемонстрували 1,92\% учнів, середній - 9,6\% дітей, відтак, вище за середній рівень динамічної сили показали 11,54\% хлопчиків і дівчаток і 76,92\% осіб, які взяли участь у тестуванні, продемонстрували високий рівень (рис. 1).

Пояснити такі високі здобутки можна двома причинами: або високим рівнем динамічної сили м'язів рук учнів 10-ти років, або заниженими нормативами їх оцінювання. Діаметрально протилежну тенденцію виявлено при аналізі результатів тестування статичної сили (вис на зігнутих руках).

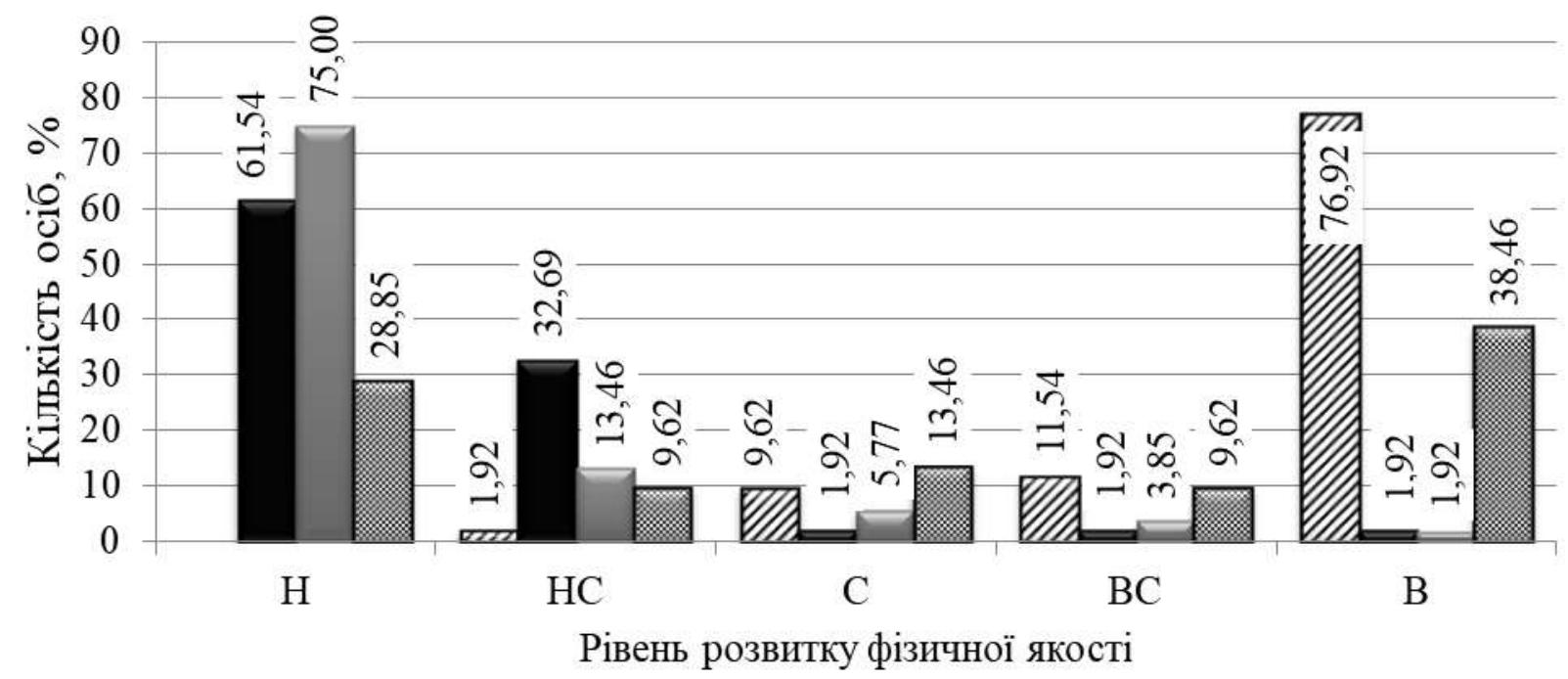

Puc. 1. Розподіл за рівнем розвитку силових здібностей школярів 10 -ти років:

- статична сила м'язів рук, $\square_{-}$динамічна сила м'язів рук; - силова витривалість м'язів ніг; 1 - динамічна сила м'язів живота 
Отже, тільки по 1,92\% учасників експерименту мали показники, що відповідали високому, вище середньому і середньому рівням розвитку статичної сили м'язів рук, нижче за середній рівень розвитку цієї здібності виявлено у $32,69 \%$ школярів, а низький - у $61,54 \%$ дітей.

Щодо показників силової витривалості м'язів ніг, то 3/4 школярів проявили низький рівень ії сформованості, 13,46\% - нижчий за середній і тільки в $11,54 \%$ - середній, вище за середній та високий рівні.

Що стосується рівня розвитку динамічної сили м'язів живота у школярів 10-ти років, то результати дослідження показали, що 38,46\% школярів проявили високий рівень, 9,62\% - вищий за середній рівень, 13,46\% - показали середній, 9,62\% - нижчий за середній і 28,85\% школярів продемонструвало низький рівень розвитку динамічної сили м'язів живота.

Такі результати тестування означеної рухової якості вказують на досить достатній розвиток динамічної сили м'язів живота молодших школярів.

3 метою отримання більш повної картини готовності школярів до занять активним туризмом серед обстежуваних дітей додатково були проведені рухові тести, що дали можливість визначити оцінку таких фізичних здібностей як координаційні здібності. Для комплексної оцінки координаційних здібностей школярів були використані тести, що характеризували просторово-часові та часові параметри рухів; статичну і динамічну рівновагу; орієнтування в просторі; загальну координованість рухів, оволодіння якими є необхідними у туризмі [5].

Успішність формування орієнтаційних здібностей у молодших школярів залежить від розвитку “топографічних уявлень”: уміння дитини розуміти просторові категорії; виокремлювати протилежні сторони на собі, відтак на іншій людині; орієнтуватися в основних напрямах простору [2]. Результати тестування відчуття простору молодшими школярами за методикою [14] показали, що 9,62\% школярів показали високий рівень, $11,54 \%$ - вище середнього, 40,38\% - середній рівень розвитку цієї здібності, що дозволить їм легко орієнтуватися в просторі, на незнайомій місцевості (рис. 2).

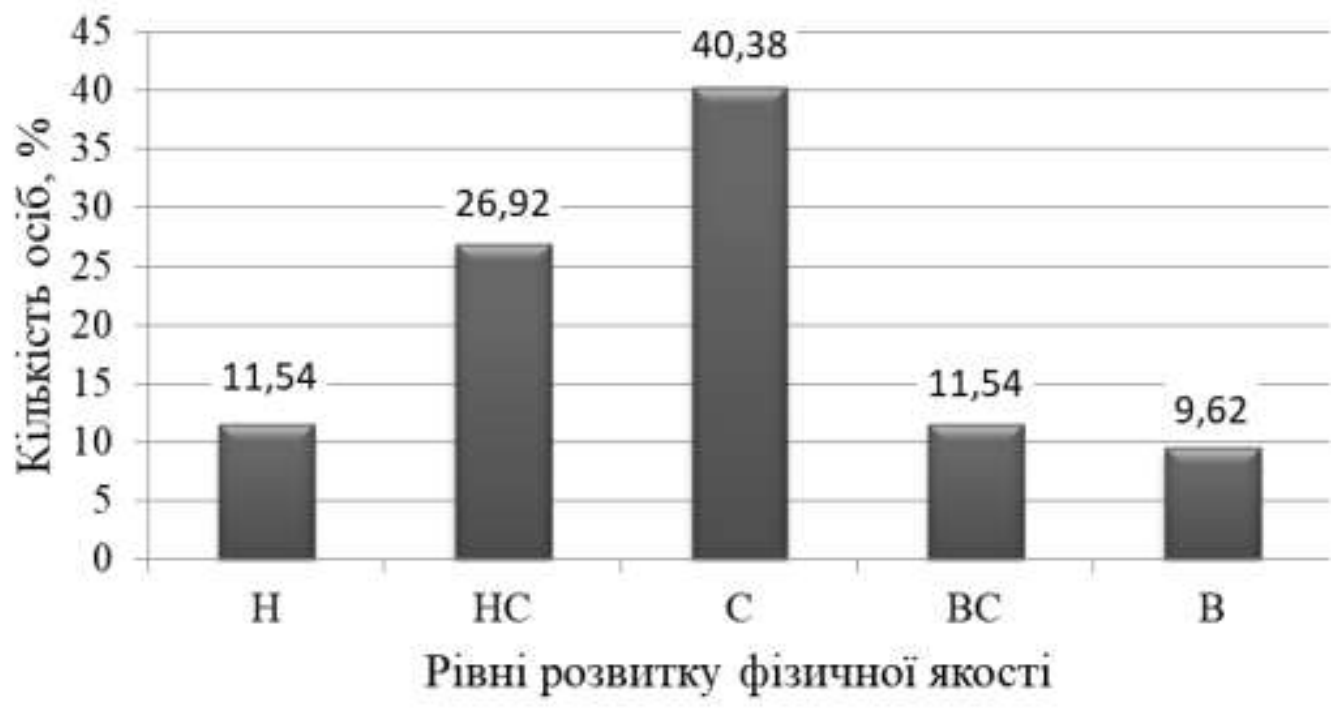

Puc. 2. Розподіл школярів 10 -ти років за рівнями розвитку відчуття простору

Однак є й такі (26,92\%), які досягли тільки нижче середнього рівня, а 11,54\% продемонстрували низький рівень відчуття простору. 
Слід відзначити, що у 65,38\% учасників тестування при диференціюванні 5- і 30секундних інтервалів часу переважали помилки зі знаком “+”, що вказує на внутрішню тенденцію уповільнення в сприйнятті часу (рис. 3).

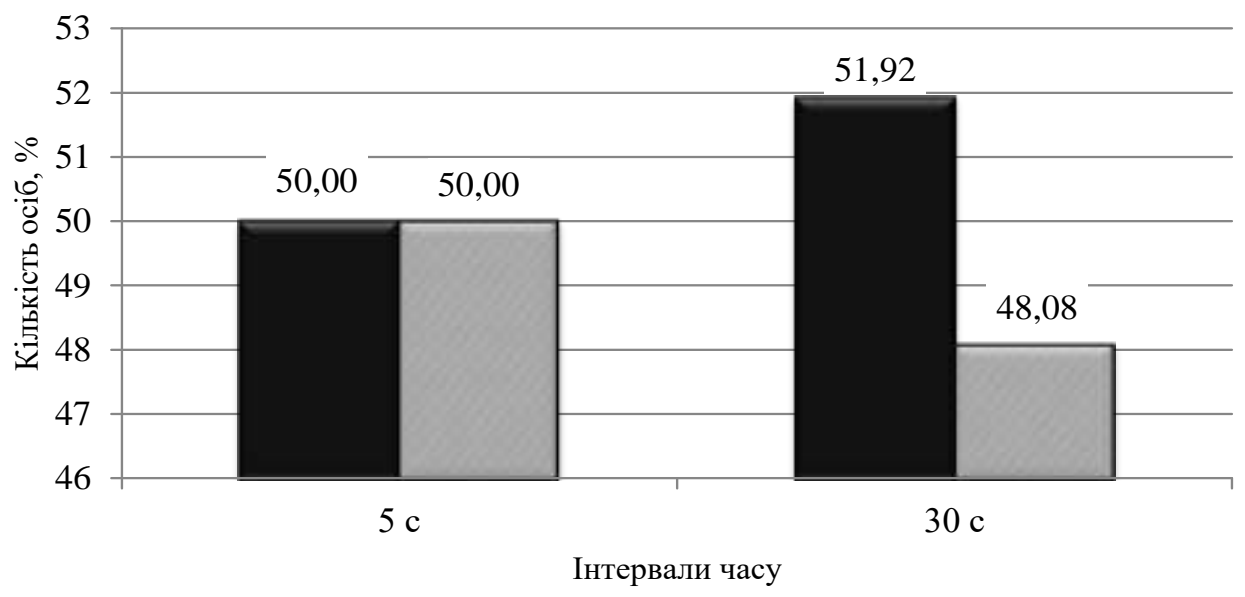

Puc. 3. Показники розвитку відчуття часу молодшими школярами 10-ти років: - типове, $\boldsymbol{Z}_{- \text {надмірне }}$

Переважання запізнілих реакцій $є$ ознакою переважання гальмівних процесів. Причиною цього могла бути втома, астенічні емоції тощо. У $34,62 \%$ респондентів переважали помилки зі знаком “-”, що вказує на внутрішню тенденцію прискорення часу. Причиною такої помилки в сприйнятті часу є мобілізація сил і енергії, стенічні емоції тощо. Випереджальна реакція вказує на неврівноваженість нервових процесів 3 переважанням збудження, що було властивим юним туристам. Значення відповідних показників у молодших школярів було близьким до заданих інтервалів, що свідчило про урівноваженість нервових процесів.

Результати оцінювання спритності (човниковий біг $3 \times 10$ м) показали, що практично немає дітей, які б проявили високий рівень їі розвитку (рис. 4). Згідно з результатами тесту, вище середнього рівня досягли 15,38\% школярів, середній проявили 9,62\% учасників тестування, нижче за середній рівень спритності виявлено у $36,54 \%$ школярів, а низький рівень продемонструвало $38,46 \%$ респондентів.

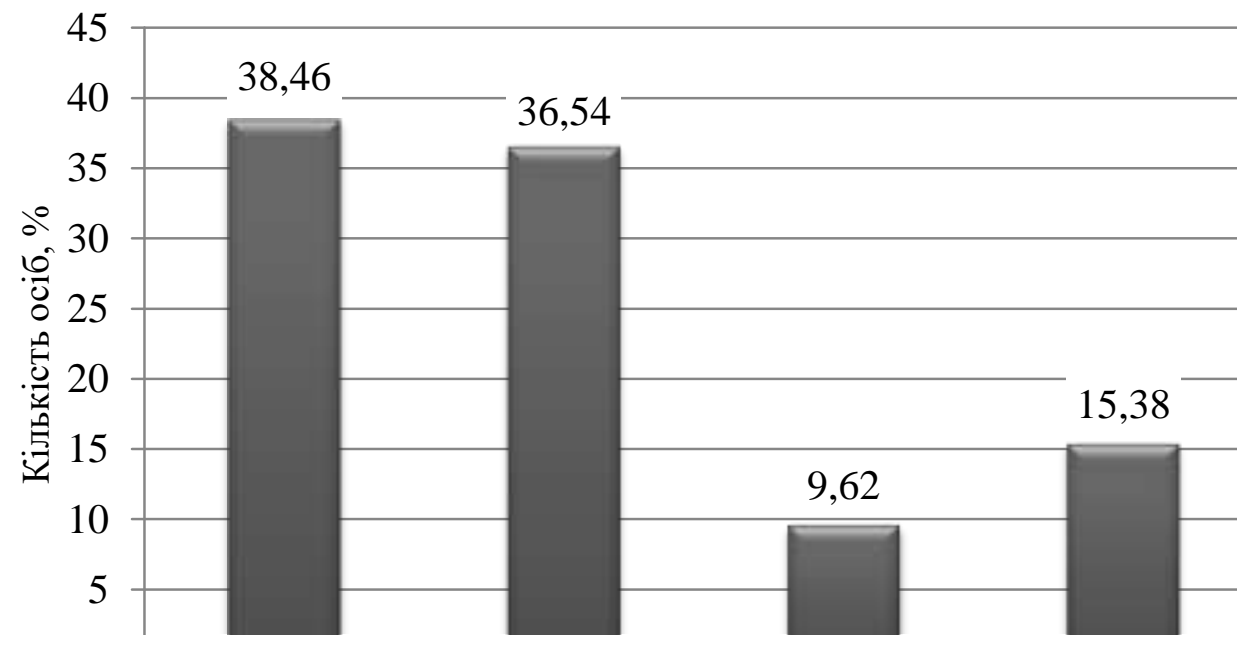

Рис. 4. Розподіл за рівнем розвитку спритності школярів 10-ти років 
При тестуванні динамічної та статичної рівноваги виявлено, що в 61,54\% учнів динамічна рівновага розвинута на високому рівні, у 26,92\% - на вищому за середній i $11,54 \%$ - на середньому рівні. Школярів із нижчим за середній і низьким рівнями сформованості означеної фізичної якості серед досліджуваного контингенту не виявлено (рис. 5).

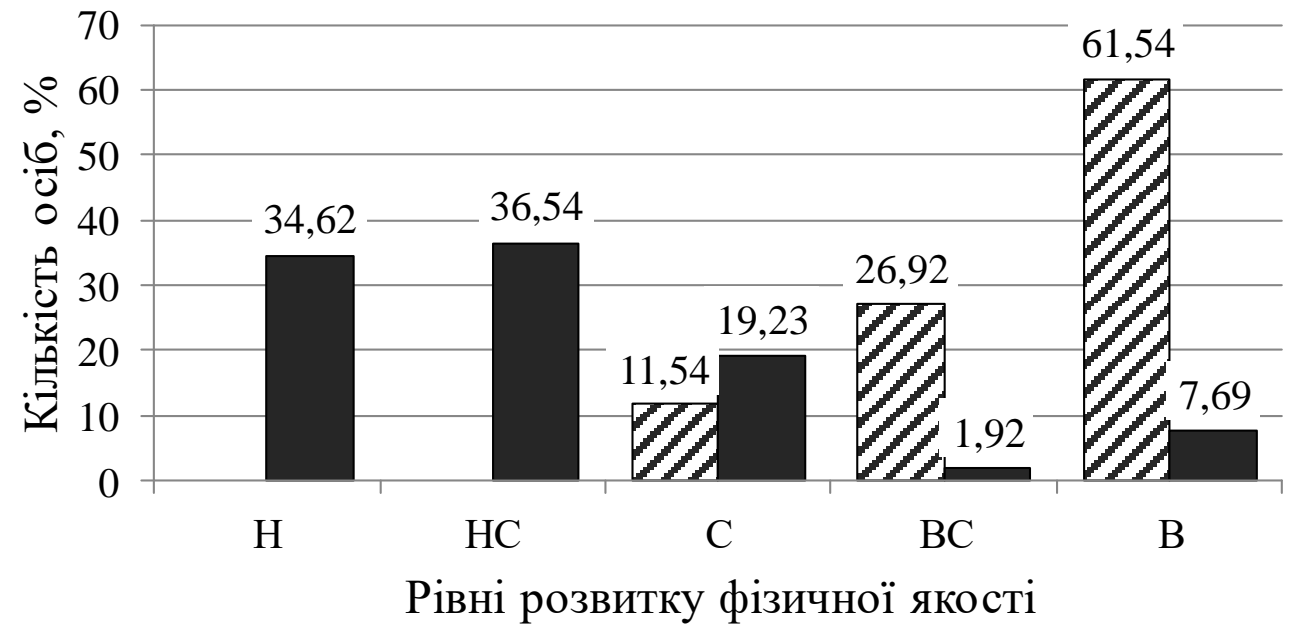

Рис. 5. Розподіл школярів 10-ти років за рівнем сформованості рівноваги:

- статична рівновага, $\mathbb{Z}$ - динамічна рівновага

Діаметрально протилежні результати ми отримали при тестуванні статичної рівноваги: 34,62\% школярів мали низький рівень, 36,54\% - нижчий за середній рівень i тільки 19,23\% - середній рівень розвитку статичної рівноваги, що є вкрай незадовільним, оскільки вище середнього і високий рівні розвитку цієї фізичної якості мали тільки 9,61\% школярів.

Не менш важливим показником фізичної підготовленості молодших школярів була загальна витривалість, позаяк рівень сформованості цієї фізичної якості у юних туристів позначатиметься на їх здатності долати чималі відстані під час туристичних походів активними способами пересування. У цьому випробуванні найбільша частка дітей продемонстрували середній (36,54\%) рівень розвитку загальної витривалості (рис. 6).

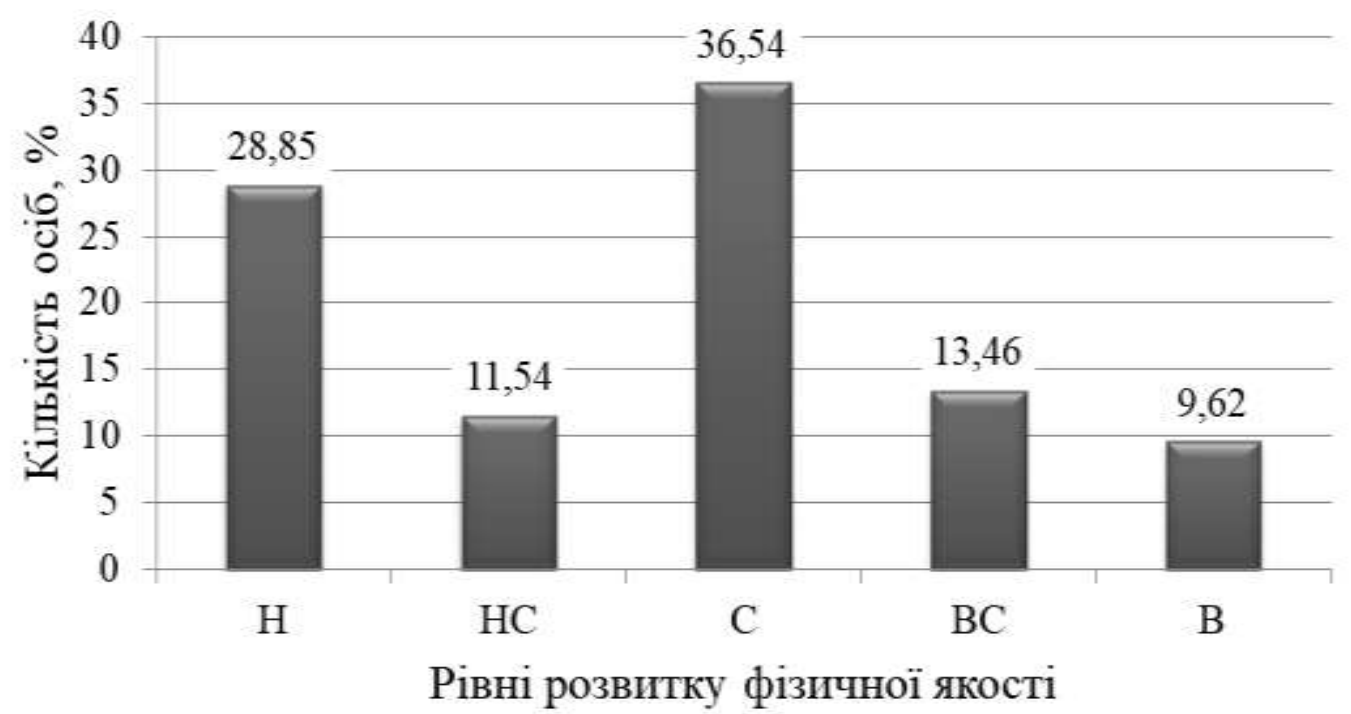

Рuc. 6. Розподіл школярів 10-ти років за рівнем сформованості загальної витривалості 
Загалом 59,62\% школярів мали рівень розвитку загальної витривалості, який дозволяє їм успішно займатися активними видами туризму.

Проте слід відзначити велику частку школярів, які мали низькі $(28,85 \%)$ і нижчі за середні $(11,54 \%)$ результати в 6-хвилинному бігу, що характеризують слабий розвиток загальної аеробної витривалості (стан серцево-судинної, дихальної та інших систем організму).

Інтегральний показник фізичної підготовленості школярів 10-ти років як критерій готовності до занять активним туризмом показав, що 65,38\% школярів наприкінці 4-го класу не готові до занять активними видами туризму і тільки трохи більше третини школярів мають достатній рівень фізичних кондицій для цього (рис. 7).

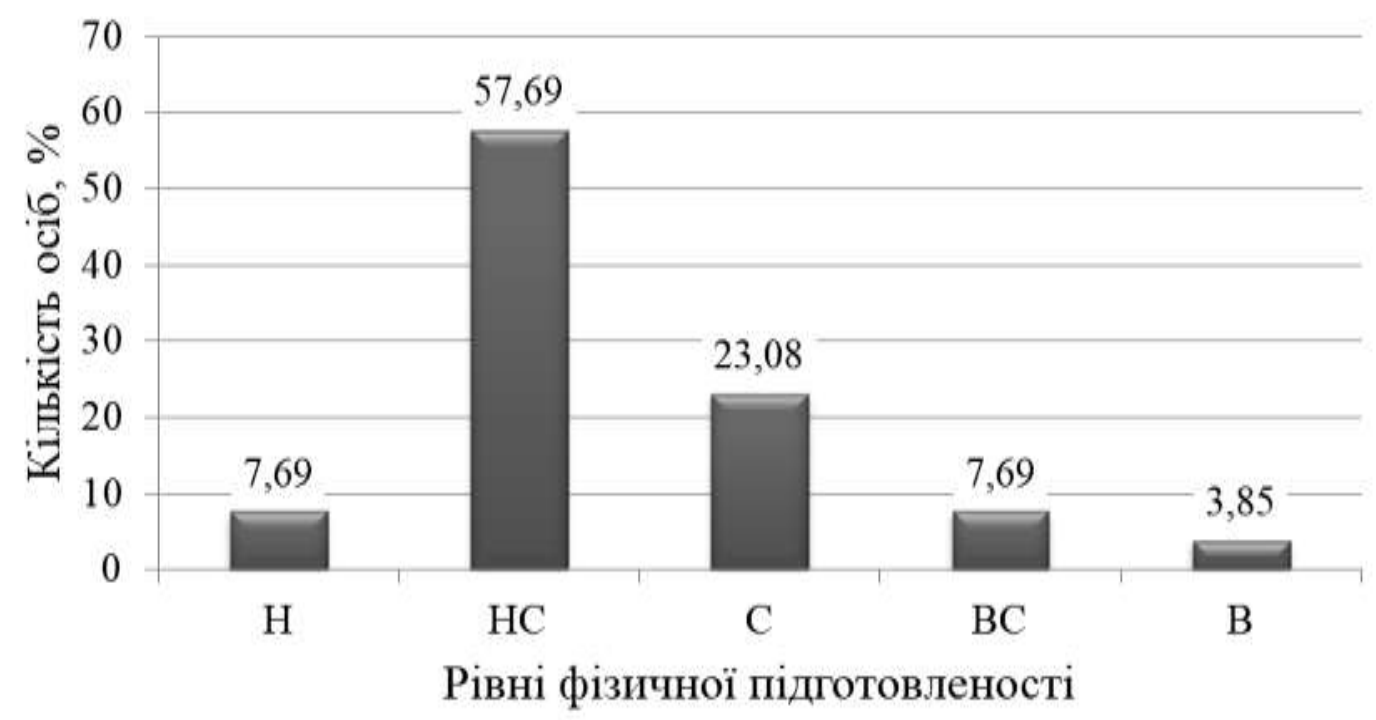

Рuc. 7. Розподіл школярів 10-ти років за рівнями інтегрального показника фізичної підготовленості

Висновки. Отже, проведене дослідження виявило, що найбільше учнів показали високий, вище середнього та середній результати щодо розвитку таких фізичних здібностей як динамічної рівноваги (100\%), динамічної сили м'язів рук $(98,08 \%)$, динамічної сили м'язів живота $(61,54 \%)$, загальної витривалості $(59,62 \%)$, а також відчуття простору $(61,54 \%)$. Однак, такі фізичні здібності як статична сила м'язів рук $(94,23 \%)$ та ніг $(88,46 \%)$, розвиток загальних координаційних здібностей $(75,00 \%)$ і статична рівновага $(71,16 \%)$ у дітей молодшого шкільного віку знаходяться на низькому і нижчому за середній рівнях розвитку.

Отримані результати свідчать про недостатню фізичну підготовленість дітей i вказують на необхідність оптимізації як урочних та і позаурочних форм фізичного виховання.

1. Аксьонова СЮ, Варбан МЮ, Васильєв ОА та ін. Державна доповідь про становище дітей в Україні (за підсумками 2015 року). К.; 2016. 200 с.

2. Гриньова ТІ, Мулик КВ. Визначення рівня фізичного здоров'я дітей 10-13 років, що займаються туризмом за авторською програмою “Туристське багатоборство”. Слобожанський науковоспортивний вісник : [нак.-теорет. журн.]. 2014; 1 (39): 22-27.

3. Довгань AI. Проблеми та перспективи розвитку туризму та краєзнавчої освіти у загальноосвітніх навчальних закладах. Туризм і краєзнавство: зб. наук. пр.: Дод. до гуманіт. вісн. ДВНЗ “ПереяславХмельницький державний педагогічний університет імені Григорія Сковороди”. ПереяславХмельницький: ФОП Лукашевич О.М.; 2014: 35. 
4. Дутчак МВ. Парадигма оздоровчої рухової активності: теоретичне обгрунтування i практичне застосування. Теорія і методика фізичного виховання і спорту. 2015; 2: 44-52.

5. Кашуба ВО, Гончарова НМ, Бутенко ГО. Ефективність використання засобів оздоровчого туризму як основи рекреаційно-оздоровчої технології у фізичному вихованні молодших школярів. Педагогіка, психологія та медико-біологічні проблеми фізичного виховання і спорту. 2016; 2: 19-25.

6. Комар ОА. Проблеми готовності майбутніх учителів фізичної культури до позакласної роботи 3 молодшими школярами. Психолого-педагогічні проблеми сільської школи; УдПУ ім. Павла Тичини. $2015 ; 1: 31-36$.

7. Коцур НІ. Туризм як один із засобів підвищення функціональних резервів організму школярів. Туризм і краєзнавство: зб. наук. пр.: Дод. до гуманіт. вісн. ДВНЗ "Переяслав-Хмельницький державний педагогічний університет імені Григорія Сковороди”. Переяслав-Хмельницький: ФОП Лукашевич О. М.; 2014: 385-391.

8. Національна доктрина розвитку освіти. URL: http://zakon3.rada.gov.ua/laws/show/347/2002 (Дата звернення: 26.11.2018).

9. Пангелова Н, Рубан В. Фактори, які впливають на організацію фізичного виховання молодших школярів у міській та сільській місцевості. Спортивний вісник Придніпров’я. 2016; 1: 211-214.

10. Руденко ВМ. Математична статистика. Навч. посіб. К.: Центр учбової літератури; 2012. 304 с.

11. Сергієнко ЛП. Тестування рухових здібностей школярів. К.: Олімпійська література; 2001. 440 с.

12. Ткачівська IM. Підготовка майбутніх учителів фізичної культури до туристсько-краєзнавчої роботи 3 учнями [автореферат]. Тернопіль: Терноп. нац. пед. ун-т ім. Володимира Гнатюка; 2009. 21 с.

13. Тюх IA. Індивідуальні норми фізичної підготовленості молодших школярів у процесі фізичного виховання [дисертація]. НУФВСУ. Київ, 2009. 166 с.

14. Фізична культура: Програма для загальноосвітніх навчальних закладів: 1-4 класи. Здоров'я та фізична культура. Шкільний світ. 2013; 6: 1-24.

15. Чалій ЛВ. Формування готовності майбутніх учителів фізичної культури до організації позакласної роботи з туризму [автореферат]. Рівне: Рівненський держ. гуманітарн.ун-т; 2017. 22 с.

\section{References}

1. Aksonova SIu, Varban MIu, Vasyliev OA ta in. Derzhavna dopovid pro stanovyshche ditei v Ukraini (za pidsumkamy 2015 roku). K.; 2016. $200 \mathrm{~s}$.

2. Hrynova TI, Mulyk KV. Vyznachennia rivnia fizychnoho zdorovia ditei 10-13 rokiv, shcho zaimaiutsia turyzmom za avtorskoiu prohramoiu "Turystske bahatoborstvo". Slobozhanskyi naukovo-sportyvnyi visnyk : [nak.-teoret. zhurn.]. 2014; 1 (39): 22-27.

3. Dovhan AI. Problemy ta perspektyvy rozvytku turyzmu ta kraieznavchoi osvity u zahalnoosvitnikh navchalnykh zakladakh. Turyzm i kraieznavstvo: zb. nauk. pr.: Dod. do humanit. visn. DVNZ "PereiaslavKhmelnytskyi derzhavnyi pedahohichnyi universytet imeni Hryhoriia Skovorody". Pereiaslav-Khmelnytskyi: FOP Lukashevych O.M.; 2014: 35.

4. Dutchak MV. Paradyhma ozdorovchoi rukhovoi aktyvnosti: teoretychne obgruntuvannia i praktychne zastosuvannia. Teoriia i metodyka fizychnoho vykhovannia i sportu. 2015; 2: 44-52.

5. Kashuba VO, Honcharova NM, Butenko HO. Efektyvnist vykorystannia zasobiv ozdorovchoho turyzmu yak osnovy rekreatsiino-ozdorovchoi tekhnolohii u fizychnomu vykhovanni molodshykh shkoliariv. Pedahohika, psykholohiia ta medyko-biolohichni problemy fizychnoho vykhovannia i sportu. 2016; 2: 19-25.

6. Komar OA. Problemy hotovnosti maibutnikh uchyteliv fizychnoi kultury do pozaklasnoi roboty $\mathrm{z}$ molodshymy shkoliaramy. Psykholoho-pedahohichni problemy silskoi shkoly; UDPU im. Pavla Tychyny. 2015; 1: 31-36.

7. Kotsur NI. Turyzm yak odyn iz zasobiv pidvyshchennia funktsionalnykh rezerviv orhanizmu shkoliariv. Turyzm i kraieznavstvo: zb. nauk. pr.: Dod. do humanit. visn. DVNZ "Pereiaslav-Khmelnytskyi derzhavnyi pedahohichnyi universytet imeni Hryhoriia Skovorody”. Pereiaslav-Khmelnytskyi: FOP Lukashevych O. M.; 2014: 385-391.

8. Natsionalna doktryna rozvytku osvity. URL: http://zakon3.rada.gov.ua/laws/show/347/2002 (Data zvernennia: 26.11.2018).

9. Panhelova N, Ruban V. Faktory, yaki vplyvaiut na orhanizatsiiu fizychnoho vykhovannia molodshykh shkoliariv u miskii ta silskii mistsevosti. Sportyvnyi visnyk Prydniprovia. 2016; 1: 211-214.

10. Serhiienko LP. Testuvannia rukhovykh zdibnostei shkoliariv. K.: Olimpiiska literatura; 2001. $440 \mathrm{~s}$.

11. Tkachivska IM. Pidhotovka maibutnikh uchyteliv fizychnoi kultury do turystsko-kraieznavchoi roboty z uchniamy [avtoreferat]. Ternopil: Ternop. nats. ped. un-t im. Volodymyra Hnatiuka; 2009. $21 \mathrm{~s}$.

12. Tiukh IA. Indyvidualni normy fizychnoi pidhotovlenosti molodshykh shkoliariv u protsesi fizychnoho vykhovannia [dysertatsiia]. NUFVSU. Kyiv, 2009. 166 s. 
13. Fizychna kultura: Prohrama dlia zahalnoosvitnikh navchalnykh zakladiv: 1-4 klasy. Zdorovia ta fizychna kultura. Shkilnyi svit. 2013; 6: 1-24.

14. Chalii LV. Formuvannia hotovnosti maibutnikh uchyteliv fizychnoi kultury do orhanizatsii pozaklasnoi roboty z turyzmu [avtoreferat]. Rivne: Rivnenskyi derzh. humanitarn.un-t; 2017. 22 s.

Цитування на цю статтю:

Ткачівська IM, Іванишин IM, Презлята ГВ, Дмитришин Д. Стан фізичної підготовленості дітей 10-ти років як критерій готовності до занять активним туризмом. Вісник Прикарпатського університету. Серія: Фізична культура. 2019 Берез 26; 33: 142-153

\begin{tabular}{|c|c|}
\hline Відомості про автора: & Information about the author: \\
\hline $\begin{array}{l}\text { Tкачівська Інна Михайлівна - кандидат педаго- } \\
\text { гічних наук, доцент, ДВНЗ “Прикарпатський на- } \\
\text { ціональний університет імені Василя Стефаника" } \\
\text { (Івано-Франківськ, Україна) }\end{array}$ & $\begin{array}{l}\text { Tkachivska Inna Mykhailivna - Candidate of Science } \\
\text { (Education), Associate Professor (Ph. D.), Vasyl } \\
\text { Stefanyk Precarpathian National University (Ivano- } \\
\text { Frankivsk, Ukraine) }\end{array}$ \\
\hline \multicolumn{2}{|l|}{$\begin{array}{l}\text { e-mail: Inna.tkachivska@gmail.com } \\
\text { https://orcid.org/0000-0002-8995-2483 }\end{array}$} \\
\hline $\begin{array}{l}\text { Іванишин Ірина Мирославівна - кандидат хіміч- } \\
\text { них наук, доцент, ДВНЗ “Прикарпатський націо- } \\
\text { нальний університет імені Василя Стефаника" } \\
\text { (Івано-Франківськ, Україна) }\end{array}$ & $\begin{array}{l}\text { Ivanyshyn Iryna Myroslavivna - Candidate of } \\
\text { Science (Chemistry), Associate Professor (Ph. D.), } \\
\text { Vasyl Stefanyk Precarpathian National University } \\
\text { (Ivano-Frankivsk, Ukraine) }\end{array}$ \\
\hline \multicolumn{2}{|l|}{$\begin{array}{l}\text { e-mail: Iraivan68@ gmail.com } \\
\text { https://orcid.org/0000-0003-1765-8311 }\end{array}$} \\
\hline $\begin{array}{l}\text { Презлята Ганна Василівна - кандидат педаго- } \\
\text { гічних наук, доцент, ДВНЗ “Прикарпатський на- } \\
\text { ціональний університет імені Василя Стефаника" } \\
\text { (Івано-Франківськ, Україна) }\end{array}$ & $\begin{array}{l}\text { Prezliata Hanna Vasylivna - Candidate of Science } \\
\text { (Education), Associate Professor (Ph. D.), Vasyl } \\
\text { Stefanyk Precarpathian National University (Ivano- } \\
\text { Frankivsk, Ukraine) }\end{array}$ \\
\hline \multicolumn{2}{|l|}{ https://orcid.org/0000-0001-9981-82 } \\
\hline $\begin{array}{l}\text { Дмитришин Дмитро Михайлович - виклада } \\
\text { Івано-Франківський національний медичний ун } \\
\text { верситет (Івано-Франківськ, Україна) }\end{array}$ & $\begin{array}{l}\text { Dmytryshyn Dmytro Mykhailovych - lecturer, Ivano- } \\
\text { Frankivsk National Medical University (Ivano- } \\
\text { Frankivsk, Ukraine) }\end{array}$ \\
\hline
\end{tabular}

УДК 796.015.134:159.9.075.5

doi: 10.15330/fcult.33.153-160

Ніна Долбишева, Анна Михайліченко

\section{ВЗАСМОЗВ'ЯЗОК ПОКАЗНИКІВ ТЕХНІЧНОЇ ПІДГОТОВЛЕНОСТІ СПОРТСМЕНІВ-ЧЕРЛІДИРІВ НА ЕТАПІ ПОПЕРЕДНЬОЇ БАЗОВОЇ ПІДГОТОВКИ}

В даній статті проаналізовані та виявлені слабкі, середні $і$ сильні взаємозв'язки показників технічної підготовленості черлідирів на етапі попередньої базової підготовки. Так як, спортсменичерлідири виконують різні функиії на гімнастичному килимі, одні спортсмени виконують базу, а інші флаєри (черлідири, які виконують безпосередньо піраміди) рівень технічної підготовленості черлідирів визначався окремо, в залежності від їх функцій. Тому $і$ корелячійний аналіз показників рівня технічної підготовленості був проведений окремо для черлідирів-бази і черлідирів-флаєрів.

Метою дослідження є виявлення найбільш сильних взаємозв'язків показників технічної підготовленості черлідирів.

Матеріал і методи. Теоретичний аналіз, педагогічне спостереження, методи математичної статистики.

У дослідженні брало участь 100 спортсменів-черлідирів, з них 50 черлідирів-флаєрів $i 50$ черлідирів-бази.

Ключові слова: черлідинг, черлідири-база, черлідери-флаєри, кореляційний аналіз, кореляційна матриця, коефіцієнти кореляиії, взаємозв'язок, технічна підготовленість. 